\title{
Retrobulbar haemorrhage following routine sub- Tenon's anaesthetic in a non-anticoagulated patient
}

\author{
Fatimah Zara Javaid, Timothy Cochrane
}

Ophthalmology Department, Maidstone Hospital, Kent, UK

\section{Correspondence to Dr Fatimah Zara Javaid; f.javaid@nhs.net}

Royal College of Ophthalmologists Annual Congress 2018

Accepted 8 January 2020
Check for updates

(C) BMJ Publishing Group Limited 2020. No commercial re-use. See rights and permissions. Published by BMJ.

To cite: Javaid FZ,
Cochrane T. BMJ Case
Rep 2020;13:e231258.
doi:10.1136/bcr-2019-
231258

\section{DESCRIPTION}

A 72-year-old myopic male patient was due to undergo routine cataract surgery for his right eye. He had undergone no previous eye surgery and preoperative measurements were unremarkable.

Preoperative visual acuity (VA) for the right eye (RE) was counting fingers (unaided), 6/18 (best corrected visual (BCV) acuity) and 6/18 (unaided) and 6/12 (BCV) for the left eye (LE). Axial length measured $23.64 \mathrm{~mm}$ and Anterior Chamber (AC) depth was $3.38 \mathrm{~mm}$ for the right eye. The left eye measured $23.64 \mathrm{~mm}$ with an AC depth of $3.37 \mathrm{~mm}$. He had a history of primary open angle glaucoma and was treated with $\mathrm{g}$. Travoprost $0.004 \%$ one drop once daily in both eyes, brinzolamide $1 \%$ one drop two times a day in both eyes for over 10 years. Of significance, slit lamp examination showed nuclear sclerotic cataract in both eyes, cup to disc ratio was 0.6 on the right and 0.7 on the left. Intraocular pressure (IOP) measurements preoperatively were $12 \mathrm{~mm}$ $\mathrm{Hg}$ in both eyes. Blood pressure on admission was 158/87 and PO medication included omeprazole $10 \mathrm{mg}$ OD, and naproxen $250 \mathrm{mg}$ PRN, which the patient reports he did not use regularly.

Prior to surgery, an experienced ophthalmic surgeon administered $5 \mathrm{~mL}$ lidocaine $2 \%$ into the sub-Tenon's space with a single-use 19G curved, blunt-end, sub-Tenons cannula. Westcott scissors were used to dissect the inferonasal conjunctiva to access the sub-Tenons space. The patient reported no discomfort immediately postprocedure and there was minimal chemosis.

On transfer to theatre, approximately $5 \mathrm{~min}$ following anaesthetic, it was noted the eye had become tense and there was proptosis with resistance to retropulsion. On further clinical examination, retrobulbar haemorrhage was diagnosed and emergency lateral canthotomy performed releasing a large volume of blood with immediate resolution of proptosis (figure 1). IOP measurements taken 2 hours post canthotomy were recorded as $22 \mathrm{~mm} \mathrm{Hg}$. The patient was discharged and reviewed 2 days later; there was full range of eye movements, no proptosis and visual acuity was $6 / 18$. IOP in the RE was $14 \mathrm{~mm} \mathrm{Hg}$. Further examination 3 weeks post canthotomy revealed a healed scar with no ectropion. IOP in the RE was $22 \mathrm{~mm} \mathrm{Hg}$ and BCV unchanged at 6/18.

A systematic review comparing topical versus sub-Tenon's anaesthesia (STA) in cataract surgery found that the latter was associated with: better analgesia; better operating conditions; reduced

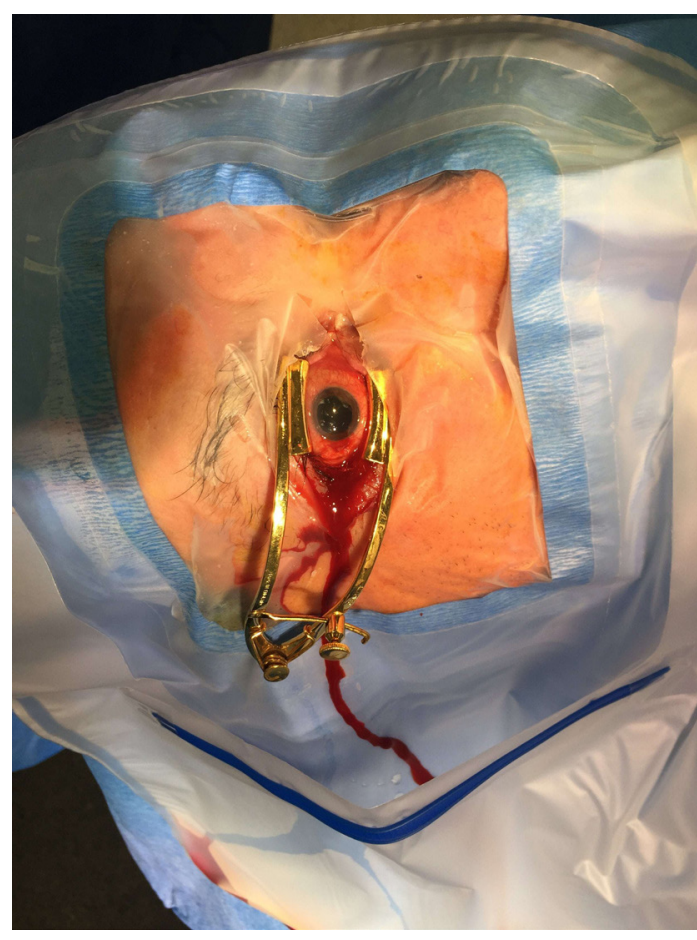

Figure 1 Intraoperative photo. Right eye post lateral canthotomy.

rate of posterior capsular tear; reduced rate of vitreous loss. ${ }^{1}$

Serious complications are reported as 2.5 times more likely to occur with peribulbar/retrobulbar anaesthesia than sub-Tenons anaesthetic. ${ }^{2}$ Previous cases of retrobulbar haemorrhage have been associated with anticoagulant use ${ }^{3}$ or large axial length. ${ }^{4}$

It is assumed in the reported cases in the literature, that rigid metal posterior cannulas were used. Riad et $a l^{5}$ compared flexible cannulas with rigid ones for STA with comparable akinesia results and presumably better safety. A low-volume subTenons such as $1.5 \mathrm{~mL}$ has been indicated to have

\section{Learning points}

Use of a rigid metal posterior cannula is associated with higher rate of complications.

- Shorter, flexible cannula reduces incidence of chemosis.

- Lower volume of anaesthetic agent is safer.

- Anticoagulation may have an effect on the response to local anaesthetic injection. 
'good anaesthesia' and 'varying akinesia' but no comparable data with the conventional larger volumes. ${ }^{6}$

Possible mechanisms for this outcome could be attributed to the use of a rigid metal cannula advancing into the posterior sub-Tenons space close to vortex veins.

Contributors FZJ: planning, drafting and reporting of the work described in the article. TC: revising it critically for important intellectual content and final approval of the version to be published.

Funding The authors have not declared a specific grant for this research from any funding agency in the public, commercial or not-for-profit sectors.

Competing interests None declared.

Patient consent for publication Obtained.
Provenance and peer review Not commissioned; externally peer reviewed.

\section{REFERENCES}

1 Davison M, Padroni S, Bunce C, et al. Sub-Tenon's anaesthesia versus topical anaesthesia for cataract surgery. Davison M, ed.. Cochrane database Syst Rev 2007:3:CD006291

2 Eke T, Thompson JR. Serious complications of local anaesthesia for cataract surgery: a 1 year national survey in the United Kingdom. Br J Ophthalmol 2007:91:470-5.

3 Rahman I, Ataullah S. Retrobulbar hemorrhage after sub-Tenon's anesthesia. J Cataract Refract Surg 2004;30:2636-7.

4 Subbiah S, McGimpsey S, Best RM. Retrobulbar hemorrhage after sub-Tenon's anesthesia. J Cataract Refract Surg 2007;33:1651-2.

5 Riad W, Ahmad N, Kumar CM. Comparison of metal and flexible sub-Tenon cannulas. J Cataract Refract Surg 2012;38:1398-402.

6 Kumar CM. Low volume sub-Tenon's block. Anaesthesia. Anaesthesia 2007:62:970-1.

Copyright 2020 BMJ Publishing Group. All rights reserved. For permission to reuse any of this content visit

https://www.bmj.com/company/products-services/rights-and-licensing/permissions/

BMJ Case Report Fellows may re-use this article for personal use and teaching without any further permission.

Become a Fellow of BMJ Case Reports today and you can:

- Submit as many cases as you like

- Enjoy fast sympathetic peer review and rapid publication of accepted articles

- Access all the published articles

Re-use any of the published material for personal use and teaching without further permission

Customer Service

If you have any further queries about your subscription, please contact our customer services team on +44 (0) 2071111105 or via email at support@bmj.com.

Visit casereports.bmj.com for more articles like this and to become a Fellow 